\title{
IMPACT OF BANK STABILIZATION STRUCTURES ON UPSTREAM AND DOWNSTREAM BANK MOBILIZATION AT CEDAR RIVER, NEBRASKA
}

\author{
Matthew V. Russel11, Aaron R. Mittelstett ${ }^{1, *}$, R. Matthew Joeckel ${ }^{2}$, \\ Jesse T. Korus', Celso F. Castro-Bolinaga ${ }^{3}$ \\ ${ }^{1}$ School of Natural Resources, University of Nebraska-Lincoln, Nebraska, USA. \\ 2 Department of Biological Systems Engineering, University of Nebraska-Lincoln, Nebraska, USA. \\ ${ }^{3}$ Department of Biological and Agricultural Engineering, North Carolina State University, Raleigh, N.C., USA. \\ *Correspondence: amittelstet2@unl.edu.
}

\section{Highlights}

- Stabilization structures are only effective at stabilized segments.

- Erosion increased in two of the six segments in the post-stabilization period.

- Deposition decreased in all six segments in the post-stabilization period.

- Jetties are effective at reducing erosion but are also prone to fail.

ABSTRACT. The effectiveness of streambank stabilization structures is insufficiently quantified. Although such structures clearly reduce or eliminate streambank erosion at the local scale, little is known about associated effects on unstabilized reaches immediately upstream and downstream. This study measured streambank erosion and deposition in stretches of the Cedar River, 1.5 meander wavelengths upstream and downstream from 24 stabilization structures that included jetties, rock vanes, root wads, and gravel protection. We also measured erosion and deposition on the streambanks directly opposite the stabilized locations. We compared measurements from the pre-stabilization period (1993-2005) with those from the poststabilization period (2005-2018) using historical imagery in ArcGIS. Upon completion of this analysis, we were able to reject an initial hypothesis that local and adjacent streambank segment erosion rates would be significantly less after stabilization, and that deposition rates would be greater in stabilized locations and adjacent stream segments. Instead, the differences in erosion from pre- to post-stabilization showed little or no statistical significance. Rather, our data indicated that streambank erosion decreased in only four of the six stream segments and was predominantly confined to the stabilized segment. Overall deposition decreased in all six stream segments after bank stabilization. In reaches where wooden jetties were installed, partial or total failure was common, and further increases in erosion and decreases in deposition were more pronounced. We conclude that streambank stabilization on the Cedar River is effective only at the location of installation; there is no measurable effect on adjacent unstabilized reaches. Our results demonstrate the need for improved streambank monitoring practices and better understanding of how streambank stabilization impacts an entire river system. Such advances will enhance stream restoration design and implementation, as well as support future river management efforts.

Keywords. Adjacent stream reach, Deposition, Jetty, Erosion, Streambank stabilization.

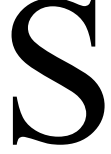
treambank stabilization structures (e.g., rock vanes, jetties) are effective at reducing, and in some cases eliminating, streambank erosion and failure at the local scale. The goal of these structures is to enhance the channel's geomorphic integrity by disrupting the hydrodynamic forces that drive streambank retreat (Khosronejad et al., 2018) or by improving the strength of streambanks (e.g., gravel protection) (Reid and Church, 2015). Additionally, streambank stabilization reduces

Submitted for review on 2 March 2021 as manuscript number NRES 14551; approved for publication as a Research Article and as part of the Streambank Erosion, Sediment Dynamics and Restoration: Monitoring, Modeling and Case Studies Collection by the Natural Resources \& Environmental Systems Community of ASABE on 9 July 2021. sediment and nutrient loading to downstream reaches, thereby improving the water quality and aquatic habitat conditions of receiving watercourses (Fox et al., 2016).

Streambank stabilization usually consists of isolated structural modifications constructed on a site-by-site basis as determined by local needs, such as the protection of infrastructure or agricultural land (Wohl et al., 2015; Bigham, 2020). These local modifications impact streamwise sediment dynamics (Enlow et al., 2018). A pronounced impact may lead to changes in flow depth, channel-bed material composition, and transport capacity, ultimately rendering stabilization structures ineffective (Pizzuto, 2008; CastroBolinaga and Fox, 2018).

Many studies have evaluated the impact of stabilization structures on streambank erosion. Bigham (2020) reviewed 
146 peer-reviewed publications on streambank stabilization systems. They observed that most studies focused on instream structures and used physical models, while streambank management techniques were assessed primarily in the field. Of the 146 reviewed studies, $68 \%$ evaluated the effect on streambank erosion. Of the 21 published studies on hardened streambanks, $62 \%$ evaluated the effectiveness of reducing or stopping streambank erosion at the area of interest. Another highlight from the review is that most of the studies focused on topics unrelated to the effects of various streambank stabilization structures. Instead, the primary focus for $80 \%$ of the studies was on how in-stream structures influence sediment transport processes in the stream (Bigham, 2020). Also absent from most of the review, and thus a large part of the available literature, is how dominant erosion processes (fluvial erosion, subaerial processes, and mass wasting) impact erosion rates, and how those rates change as the dominant processes change over time (Couper, 2004; Simon et al., 2000).

Although most studies aim to assess the site-scale effects that streambank stabilization has on streambank erosion at the local scale, the need for broader, long-term site evaluations has been consistently emphasized in the literature (Anstead et al., 2012; Bhuyian et al., 2009; Buchanan et al., 2014; Cooperman, 2007; Enlow et al., 2018). To make this transition, several field sites, as well as before-after-controlimpact studies (BACI), are vital in creating a dataset large and comprehensive enough to evaluate the long-term impacts of stabilization structures in natural settings (Cooperman et al., 2007). Assessment of these projects and their effects on the whole stream and/or watershed scale, and conversely the entire watershed's impact on streambank stability and the stream's evolutionary stage, is critical to better understand and improve streambank stabilization structures (Anstead et al., 2012; Buchanan et al., 2014; Cooperman et al., 2007; Enlow et al., 2018; Florsheim et al., 2008; Rosgen, 1996; Wohl et al., 2015). In this study, we employed methods to assess streambank techniques on a whole-stream basis, with the intention of addressing the deficiencies outlined by Bigham (2020). We specifically addressed the need for long-term studies that assess the whole-stream impacts of streambank stabilization structures.

The Cedar River is a dynamic watercourse that originates in the Nebraska Sandhills. Its streambanks have been stabilized, successfully or unsuccessfully, with various techniques over a period of many decades. Two previous studies conducted on the Cedar River evaluated the effectiveness of streambank stabilization structures on streambank erosion and deposition (Dave and Mittelstet, 2017; Russell et al., 2021). Dave and Mittelstet (2017) quantified the streambank retreat before $\left(0.45 \mathrm{~m}^{2} \mathrm{~m}^{-1}\right.$ year $\left.{ }^{-1}\right)$ and after $\left(0.16 \mathrm{~m}^{2} \mathrm{~m}^{-1}\right.$ year $^{-1}$ ) the stabilization of 18 streambanks. They found that the stabilized banks were more efficient than the control sites at reducing erosion. Russell et al. (2021) evaluated streambank retreat and deposition at three banks stabilized with wooden jetties on the Cedar River. They found that the jetties both reduced erosion and increased deposition. While both studies quantified the erosion and deposition at the stabilized bank, neither evaluated the impact of the stabilization structure upstream or downstream.
Therefore, the objectives of the present study are to quantify the erosion and deposition upstream and downstream of the stabilized streambank, as well as for the opposite bank, before (1993-2006) and after (2006-2018) the streambanks were stabilized. Based on the findings from Dave and Mittelstet (2017), we hypothesized that the (1) local and adjacent streambank segment erosion rates would be significantly less after stabilization, and (2) deposition rates would be greater in stabilized locations and adjacent stream segments after stabilization. We tested these hypotheses by comparing remotely sensed data for pre-bank stabilization and post-bank stabilization using ArcGIS and historical aerial imagery.

\section{MATERIALS AND METHODS STUDY SITE}

The Cedar River, which originates in the eastern edge of the Nebraska Sandhills in north central Nebraska, flows approximately $200 \mathrm{~km}$ to the Loup River south of Fullerton, Nebraska (fig. 1). The $3200 \mathrm{~km}^{2}$ watershed is predominantly grassland and sand dunes in the west and gradually changes to cropland in the central Nebraska Loess Hills and Loess Uplands in the eastern part of the watershed. The streambanks, which are 0.4 to $4.0 \mathrm{~m}$ in height, are predominantly sand and silt (Dave and Mittelstet, 2017). The average discharge from 2006 to 2016 was $5.6 \mathrm{~m}^{3} \mathrm{~s}^{-1}$ and $8.4 \mathrm{~m}^{3} \mathrm{~s}^{-1}$ at the gauge stations near Spalding and Fullerton, Nebraska, respectively (NEDNR, 2021). There are dams on the Cedar River at Ericson and Spalding (fig. 1). In June 2010, the dam at Ericson Lake Reservoir breached after multiple days of precipitation. During the ensuing flood, discharge peaked at $190.4 \mathrm{~m}^{3} \mathrm{~s}^{-1}$, a value nearly three times greater than the nexthighest discharge on record (1944-current) (Dave et al., 2020). The flood caused $2820 \mathrm{~m}^{2} \mathrm{~km}^{-1}$ year-1 of streambank erosion, compared to 576 and $384 \mathrm{~m}^{2} \mathrm{~km}^{-1}$ year ${ }^{-1}$ for the preflood and post-flood periods, respectively (Dave et al., 2020). Nearly $30 \%$ of all streambank erosion from 2006 to 2016 was generated by this one extreme flood event.

\section{STREAMbank Stabilization STRUCTURES}

Historically, landowners along the Cedar River have been affected by erosion along the river. In the early 2000s, the Loup Basin Resource Conservation and Development Council, in collaboration with landowners along the river, received two grants to stabilize at least 24 streambanks on the Cedar River (Loup Basin RC\&D, 2021). Six types of structures were installed in 2005, including 13 wooden jetties, four tree jetties, one reinforced concrete wall, three rock vanes, one root wad, and four sloped gravel banks (one reach has both tree jetties and a sloped gravel bank). Stabilization structures generally have two functions: (1) reduce applied hydrodynamic force and (2) increase streambank strength by modifying or adding streambank material. Each of the structures used on the Cedar River provides these two functions.

Wooden jetties (fig. 2a) consist of two or three vertical posts and one horizontal tree trunk. In many cases, the structure has woody vegetation (red cedar saplings, shrubs, etc.) tied throughout the posts to increase the streambank area 


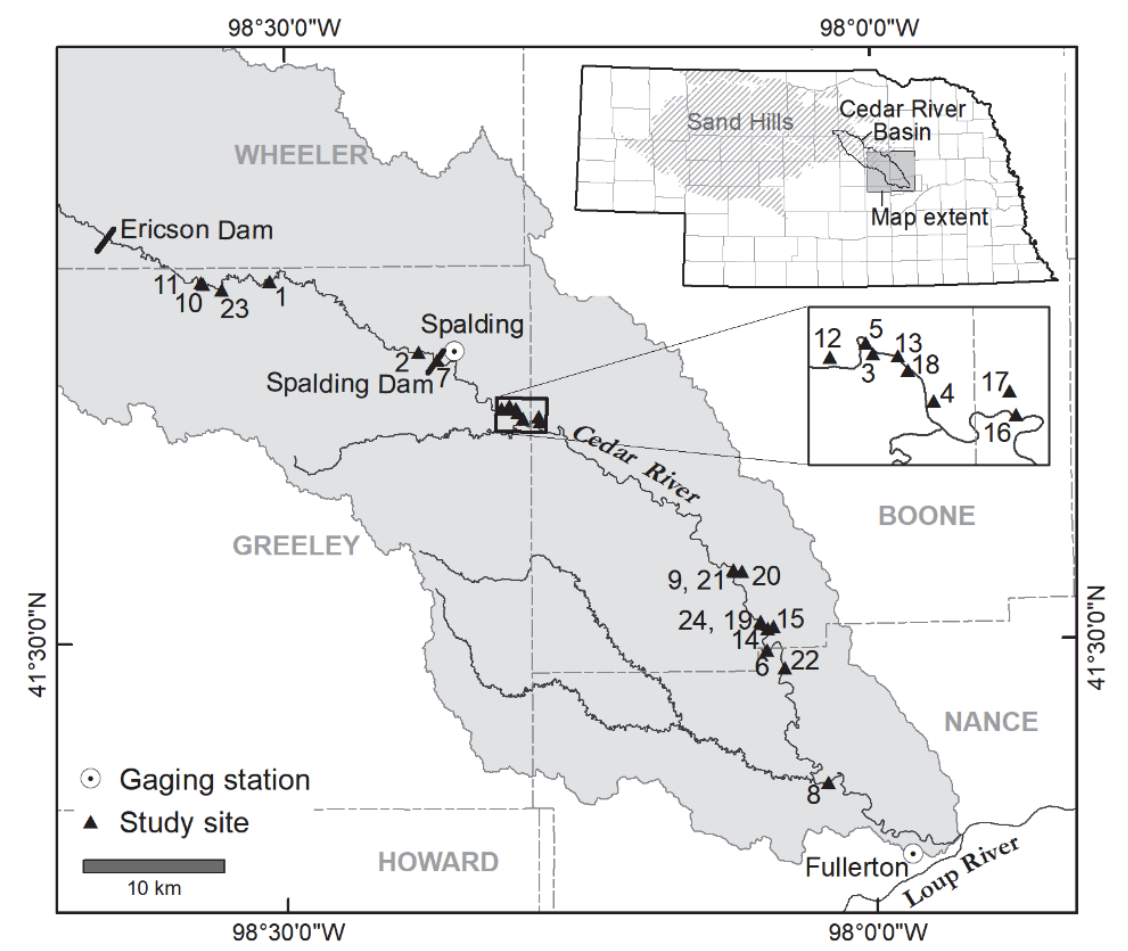

Figure 1. Location of 24 study sites and Ericson and Spalding Dams on the Cedar River in Nebraska.
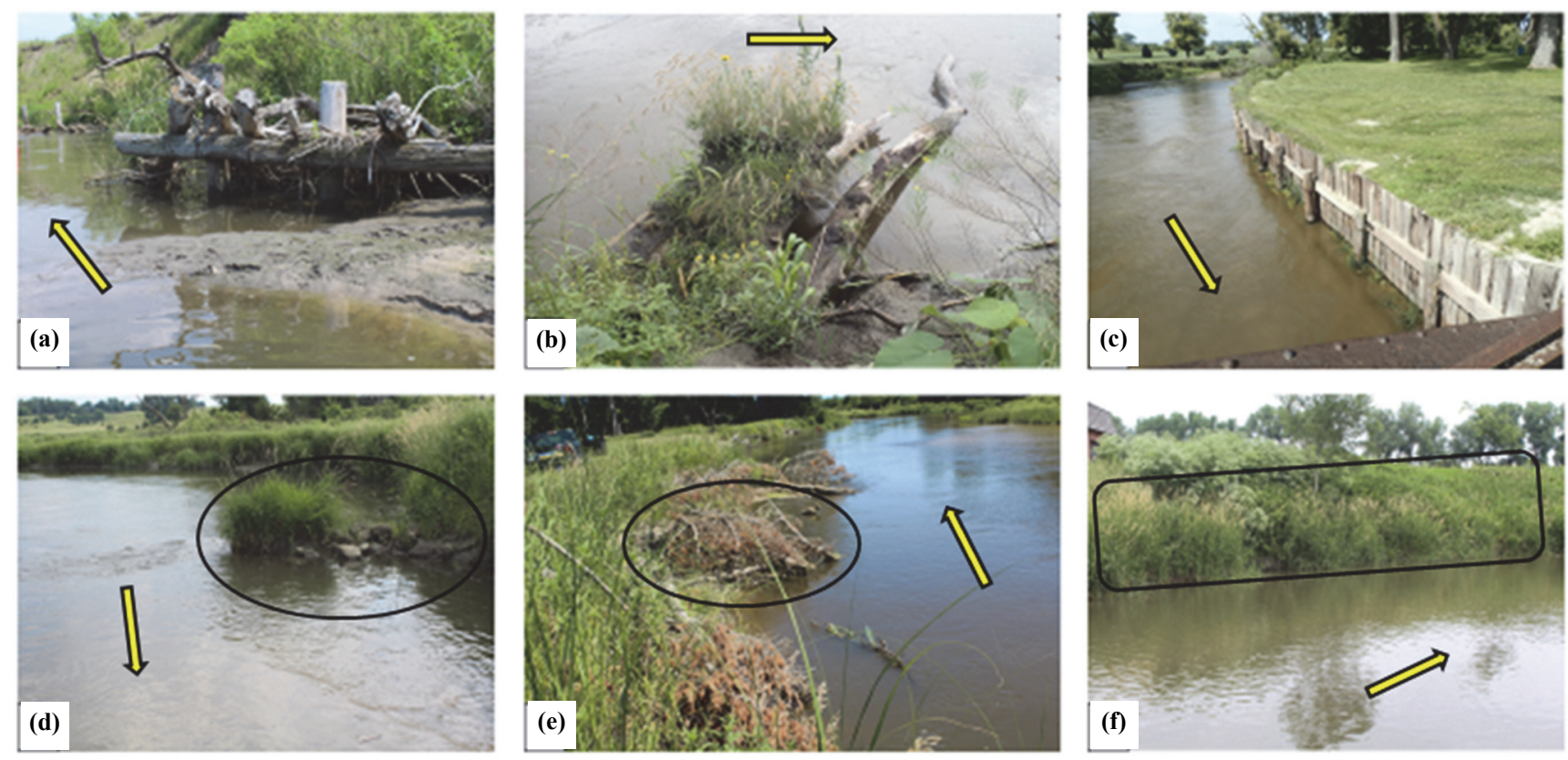

Figure 2. Six different types of stabilization structures were assessed during this project: (a) wooden jetty, (b) tree revetment, (c) reinforced concrete wall, (d) rock vane, (e) root wad, (f) and sloped gravel bank. Yellow arrows indicate flow direction.

protected by the structure. The jetties are angled downstream and are used to slow and deflect flow. Tree revetments (fig. 2b) are similar in structure to wooden jetties. In these structures, a tree trunk is keyed into the streambank with its roots into the bank, with no vertical support, and is angled downstream to deflect flow and reduce velocity. The reinforced concrete wall (fig. 2c) was located directly downstream of Spalding Dam and was likely constructed because of its strength relative to other stabilization practices. Rock vanes (fig. 2d) consist of rip rap extending from the toe of the bank into the river, angled upstream, and are intended to decelerate flow and protect the bank. A root wad (fig. 2e) is like a tree revetment, except that the bottom of the trunk and its roots are exposed in the channel flow to dissipate the hydrodynamic forces acting on the bank. Sloped gravel banks (fig. 2f) have gravel added on top of various erosion control fabrics and materials. This combination of bank slope reduction, stabilization, and increased material strength creates an environment that is optimal for vegetation growth, further strengthening the streambank. All reaches with sloped gravel 
Table 1. Each site had one or more stabilized segments within the examined reach. These stabilized segments were documented based on their location and the percentage of the stabilized area within the segment, as well as the percentage of each segment that was stabilized, e.g., $100 \%$ of the stabilization found at site 13 was in segment US1R, and $20.4 \%$ of that segment had a stabilized bank.

\begin{tabular}{|c|c|c|c|}
\hline Site & $\begin{array}{l}\text { Stabilized } \\
\text { Segments }\end{array}$ & $\begin{array}{c}\text { Percentage of } \\
\text { Stabilized Area } \\
\text { in Segment }\end{array}$ & $\begin{array}{c}\text { Percentage of } \\
\text { Segment that } \\
\text { was Stabilized }\end{array}$ \\
\hline \multirow[t]{2}{*}{1} & US1L & 31.6 & 10.8 \\
\hline & DS1L & 68.4 & 21.0 \\
\hline \multirow[t]{2}{*}{2} & US1R & 24.0 & 22.6 \\
\hline & DS1R & 75.9 & 12.6 \\
\hline 3 & US1L & 100 & 19.7 \\
\hline \multirow[t]{2}{*}{4} & US1R & 16.2 & 6.0 \\
\hline & DS1R & 83.8 & 20.7 \\
\hline \multirow[t]{2}{*}{5} & US1R & 43.3 & 18.4 \\
\hline & DS1R & 56.7 & 29.9 \\
\hline 6 & DS1R & 100 & 38.3 \\
\hline \multirow[t]{2}{*}{7} & US1R & 51.5 & 25.7 \\
\hline & DS1R & 48.5 & 3.2 \\
\hline 8 & US1L & 100 & 34.5 \\
\hline 9 & DS1R & 100 & 29.4 \\
\hline 10 & DS1L & 100 & 41.2 \\
\hline \multirow[t]{2}{*}{11} & US1R & 65.0 & 31.4 \\
\hline & DS1R & 35.0 & 24.7 \\
\hline \multirow[t]{2}{*}{12} & US1R & 15.6 & 12.2 \\
\hline & DS1R & 84.4 & 73.7 \\
\hline 13 & US1R & 100 & 20.4 \\
\hline 14 & US1L & 100 & 45.3 \\
\hline 15 & DS1L & 100 & 61.1 \\
\hline $16^{[\mathrm{a}]}$ & DS1R & 100 & 51.3 \\
\hline $17^{[\mathrm{a}]}$ & US1L & 100 & 56.9 \\
\hline 18 & DS1L & 100 & 30.8 \\
\hline 19 & US1L & 100 & 49.1 \\
\hline \multirow[t]{2}{*}{$20^{[\mathrm{a}]}$} & US1R & 18.7 & 12.1 \\
\hline & DS1R & 81.3 & 60.8 \\
\hline 21 & US1L & 100 & 29.8 \\
\hline 22 & US1L & 100 & 8.9 \\
\hline 23 & US1R & 100 & 12.2 \\
\hline $24^{[\mathrm{a}]}$ & DS1R & 100 & 21.9 \\
\hline
\end{tabular}

a] Percentages were estimated based on site visits because the stabilization structure was not visible in aerial images from 2006 or later.

Landowner accounts provided during the site visits were used to determine the stabilization structure type and location in the reach.

banks were completely vegetated with grass at the time of site visits. Five of the reaches lie between the Ericson and Spalding Dams (fig. 1). Reaches 10 and 11 are approximately $8 \mathrm{~km}$ downstream from Ericson Dam. The remaining 19 study reaches were located downstream of Spalding Dam. Reach 8 , the farthest downstream, is approximately $72 \mathrm{~km}$ downstream of Ericson Dam (table 1).

\section{MEASUREMENT OF STREAMbank EROSION AND DEPOSITION}

There is no established standard method for evaluating the upstream and downstream influence of stabilization structures. We initially considered evaluating the upstream and downstream segments using a constant downstream distance (e.g., $100 \mathrm{~m}$ ). We rejected this approach because it precludes the comparison of analogous parts of the river's planform; consequently, it would produce incongruent data. The use of a constant distance, particularly a relatively short distance, might entail the collection of data from an entire meander at one location, only a partial meander at another location, and a straight stretch at a different location. Therefore, we opted to quantify the erosion and deposition at 1.5 meander wavelengths upstream and downstream of each stabilized location.

We divided each reach into six segments defined according to inflection points where the curvature of the stream channel changes direction. Reach is defined as the study site encompassing all six segments based on the inflection points. The distance between two inflection points constitutes a full wavelength, or a single meander (Leopold et al., 1957). We used the 2006 aerial image to identify inflection points and then used the same located points in all other images, whether they preceded or succeeded that aerial photograph year (fig. 3). The midpoints of the upstream and downstream sections were the areas of streambank stabilization (fig. 3). Each new river segment began at each inflection point of the following meander and continued until the next inflection point. The six segments were labeled upstream 1 (US1), upstream 2 (US2), upstream 3 (US3), downstream 1 (DS1), downstream 2 (DS2), and downstream 3 (DS3). Channel migration and abandonment, including the formation of oxbows, precluded the assessment of certain segments in certain aerial photograph years.

We assessed channel migration for two periods: 19932006 (pre-stabilization) and 2006-2018 (post-stabilization) (fig. 3). Erosion and deposition were measured for both the left (L) and right (R) streambanks, so there were a total of 24 measurements for each study location for the two time periods: DS1 erosion and deposition for the right (DS1R) and left (DS1L) banks (4 measurements), DS2 erosion and deposition for the right and left banks (4 measurements), DS3 erosion and deposition for the right and left banks (4 measurements), US1 erosion and deposition for the right and left banks (4 measurements), US2 erosion and deposition for the right and left banks (4 measurements), and US3 erosion and deposition for the right and left banks (4 measurements). A total of 48 erosion and deposition measurements were made at each study site.

For each measurement, an edge-of-bank line was drawn over each segment, for each selected year, to quantify the area of streambank that was either eroded or deposited. The area between the polylines representing the streambanks of each reach was measured with the ArcMap measuring tool similar to the method of Heeren et al. (2012). The area of each polygon was measured and recorded, and the cumulative erosion and depositional data were summed. Segment length and yearly variations in channel length were measured and recorded alongside the corresponding erosion and deposition data. Each streambank section's total erosion and deposition were normalized by dividing by segment length, resulting in a value with units $\mathrm{L}^{2} \mathrm{~L}^{-1}$.

\section{Site ChaRACTERIZATION}

For each study site, the following parameters were recorded: percentage stabilized (table 1), sinuosity $(S)$, status of stabilization structure (table 2), and the segment, or segments, in which the stabilization structure was installed (table 1). The sinuosity of each reach was calculated by dividing the length of the stream centerline from the upstream end of US3 to the downstream end of DS3 by the straight-line distance between those points. 


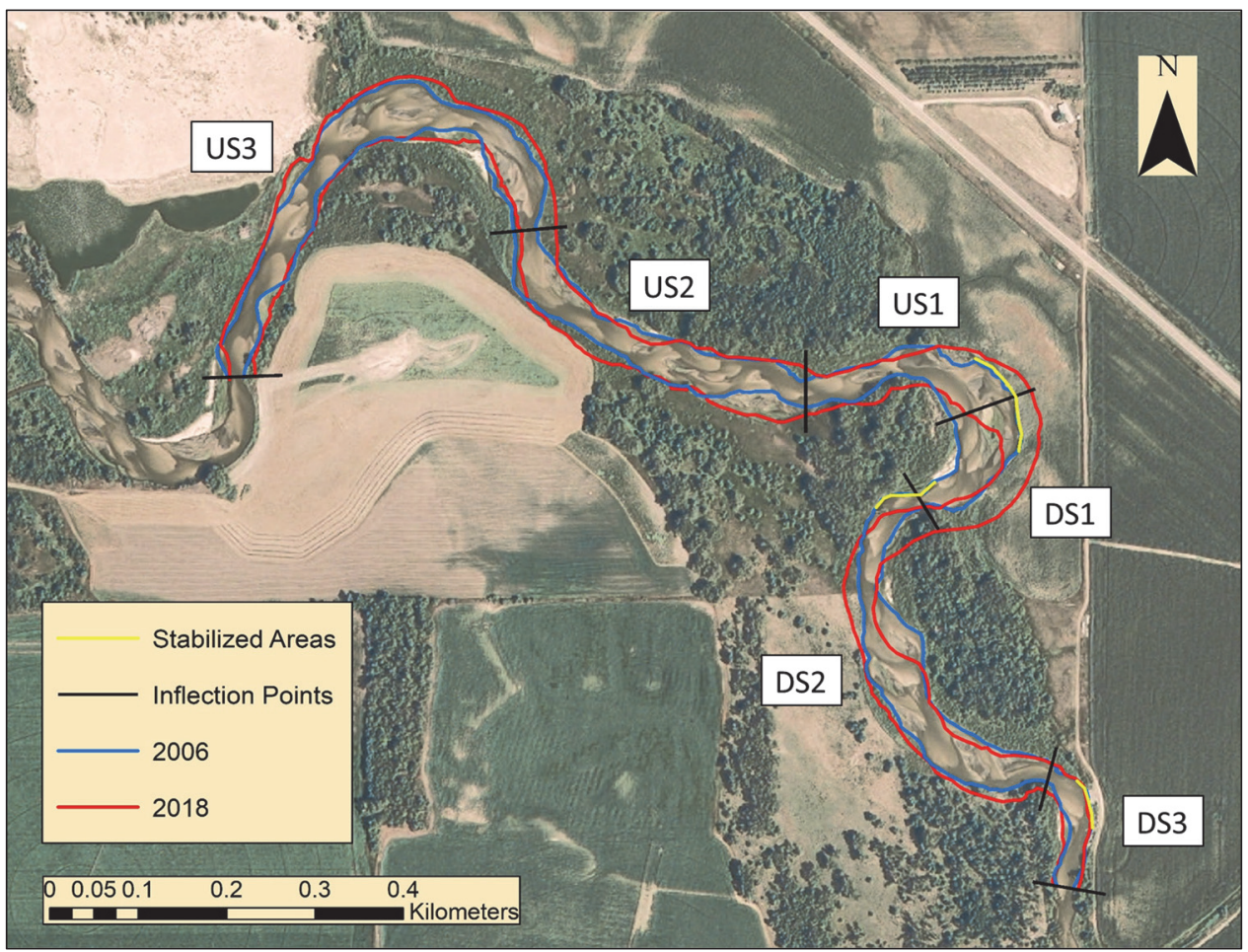

Figure 3. At site 20, each reach was divided into six segments: upstream 1 (US1), upstream 2 (US2), upstream 3 (US3), downstream 1 (DS1), downstream 2 (DS2), and downstream 3 (DS3). Stream inflection points were used to determine the lengths of the stream segments.

Table 2. Each site was categorized into functional (F), non-functional $(\mathrm{N})$, or partially functional $(\mathrm{P})$, and a sinuosity value was calculated for each site. Distance is downstream from Ericson Dam. Spalding Dam is located at km 27.

\begin{tabular}{ccccc}
\hline Site & $\begin{array}{c}\text { Stabilization } \\
\text { Structure }\end{array}$ & Functionality & Sinuosity & $\begin{array}{c}\text { Distance from } \\
\text { Ericson Dam } \\
(\mathrm{km})\end{array}$ \\
\hline 1 & Wooden jetties & $\mathrm{P}$ & 1.4 & 13 \\
\hline 2 & Rock vanes & $\mathrm{F}$ & 1.3 & 26 \\
\hline 3 & Wooden jetties & $\mathrm{P}$ & 1.7 & 34 \\
\hline 4 & Sloped gravel bank & $\mathrm{F}$ & 1.7 & 34 \\
\hline 5 & Sloped gravel bank & $\mathrm{F}$ & 1.7 & 34 \\
\hline 6 & Wooden jetties & $\mathrm{P}$ & 3.3 & 61 \\
& and rip rap & & & \\
\hline 7 & Reinforced & $\mathrm{F}$ & 1.8 & 27 \\
\hline & concrete wall & & & \\
\hline 8 & Wooden jetties & $\mathrm{P}$ & 1.1 & 72 \\
\hline 9 & Wooden jetties & $\mathrm{P}$ & 1.4 & 55 \\
\hline 10 & Sloped gravel bank & $\mathrm{F}$ & 1.5 & 8 \\
\hline 11 & Wooden jetties & $\mathrm{F}$ & 1.8 & 8 \\
\hline 12 & Root wads & $\mathrm{F}$ & 1.6 & 34 \\
\hline 13 & Rock vanes & $\mathrm{F}$ & 1.4 & 20 \\
\hline 14 & Wooden jetties & $\mathrm{F}$ & 2.0 & 63 \\
\hline 15 & Wooden jetties & $\mathrm{N}$ & 2.3 & 62 \\
\hline 16 & Tree jetties & $\mathrm{N}$ & 2.5 & 37 \\
\hline 17 & Tree jetties & $\mathrm{N}$ & 2.3 & 40 \\
\hline 18 & Wooden jetties & $\mathrm{N}$ & 1.1 & 35 \\
\hline 19 & Tree jetties & $\mathrm{F}$ & 2.0 & 62 \\
\hline 20 & Wooden jetties & $\mathrm{N}$ & 1.8 & 57 \\
\hline 21 & Wooden jetties & $\mathrm{P}$ & 1.4 & 60 \\
\hline 22 & Tree jetties & $\mathrm{F}$ & 1.3 & 63 \\
\hline 23 & Tree jetties & $\mathrm{F}$ & 1.3 & 62 \\
\hline 24 & Tree jetties & Unknown & 1.8 & 59 \\
\hline & & & & \\
\hline & & & & \\
\hline & & & \\
\hline
\end{tabular}

We visited all 24 study sites from May 2018 to August 2019 and evaluated the streambank stabilization structures in terms of their status and functionality (table 1). Fully func- tional structures (F) were entirely visible above stream level and showed no major structural damage. Partially functional structures $(\mathrm{P})$ were only partially visible and/or had structural damage. Structures that were no longer visible, having been buried or washed away, were classified as non-functional $(\mathrm{N})$.

Using ArcMap, we evaluated the segment, or segments, where the streambank was stabilized. The percentage of the length of the bank with a stabilization structure within each segment was documented, as well as the percentage of the length of the segment, or segments, that was stabilized (table 1 and fig. 3).

\section{Data ANalysis}

We calculated descriptive statistics, including mean, median, minimum, maximum, and standard deviation (SD), for the measured erosion and deposition for each river segment. An ANOVA $(\alpha=0.05)$, with Fisher post-hoc test, was completed to determine significant differences in the average erosion and deposition for the six segments for the pre- and post-stabilization periods.

The sites were grouped based on the stabilization practice and functionality. Specifically, we evaluated the erosion and deposition for the following groups: hardened structures, fully functional, partially functional, and non-functional jetties stabilization practices. The changes in erosion and deposition were calculated by finding the difference between the erosion and deposition that occurred during the pre-stabilization period from the erosion and deposition that occurred during the post-stabilization period. Each segment that had large changes between the two periods is discussed. Finally, we conducted an ANOVA to compare the erosion and 
deposition for each of these identified groups for the segment that was stabilized and the segments immediately upstream and downstream.

\section{RESULTS AND DISCUSSION}

\section{Stream Planform}

The local planform of the Cedar River is variable. The study reaches range in sinuosity from 1.1 to 3.3 . The average of these sinuosity values is 1.7 (table 2 ), which qualifies the river as a meandering stream $(S \geq 1.5)$ overall (Leopold and Wolman, 1957). Nevertheless, some reaches of the Cedar River exhibit low sinuosity, and two of them (sites 8 and 18) are effectively straight. The river's meanderbelt ranges from 0.2 to $1.2 \mathrm{~km}$ in width. The Cedar River exhibits common bank-attached, alternating compound bars, most of which qualify as point bars because they show evidence of lateral migration (e.g., meander scrolls) and adjacent cut banks. Furthermore, there are many meander cutoffs (oxbows) that appear to be of different ages on the basis of their size, water level, and geomorphic prominence. Numerous midchannel compound bars, which are mostly less than $1 \mathrm{~km}$ in length, are present at intervals along the entire length of the river. A few of these midchannel compound bars, such as at site 13 , have become stabilized by woody vegetation during the period we studied. To the extent of our knowledge, the Cedar River is an alluvial stream along its entire length, and shallow bedrock does not influence its planform characteristics.

\section{FUNCTIONALITY OF STREAMBANK STABILIZATION STRUCTURES}

The functionality of the streambank stabilization structures varied at the time of our investigation. Nearly half of the structures we inspected were either partially functional or non-functional (table 2). The partially functional and nonfunctional structures were all jetties. We could not locate the jetties known to have been installed in one reach (site 24 in table 2), and we presume that they were removed by erosion and washed downstream during high flows. In comparison, all the other types of stabilization structures installed on the Cedar River were fully functional at the time of our site visits (table 2). These observations validate the assertion of Dave and Mittelstet (2017) that jetties are the most failure-prone type of stabilization structure.

There is no documentation for why the jetties at these sites failed. Nevertheless, Dave et al. (2020) determined that erosion from the 2010 flood was much greater than the preflood (2006-2009) and post-flood (2010-2016) periods. We infer that the extreme peak flow event produced by the breach in the Ericson Dam in June 2010 likely led to the loss of function in many reaches of the Cedar River. Dave et al. (2017) measured high erosion rates $\left(2820 \mathrm{~m}^{2} \mathrm{~km}^{-1}\right)$ for the 2010 breach, compared to 576 and $384 \mathrm{~m}^{2} \mathrm{~km}^{-1}$ year ${ }^{-1}$ for the pre-flood and post-flood periods, and found that erosioncontrol structures lost functionality as far as $27 \mathrm{~km}$ downstream. Presumably, the hydrodynamic force of the dambreach flood would have had a progressively lesser impact on streambanks farther downstream; however, we observed a non-functional jetty $57 \mathrm{~km}$ downstream of the Ericson Dam and a partially functional jetty $60 \mathrm{~km}$ downstream (table 2).

\section{STREAMBANK EROSION AND DEPOSITION}

Overall, both erosion and deposition decreased after the installation of streambank stabilization structures. The average erosion for all segments was 5.6 and $3.7 \mathrm{~m}^{2} \mathrm{~m}^{-1}$ for the pre- and post-stabilization periods, respectively. These values are similar to the erosion measured by Dave and Mittelstet (2017) at 40 control sites on the Cedar River, for which the erosion for the pre- and post-stabilization periods was 4.1 and $4.0 \mathrm{~m}^{2} \mathrm{~m}^{-1}$, respectively. Only segments US3 and US1 exhibited increases in erosion. The largest reductions in erosion were in segments DS2 and DS3. In fact, mean values of both erosion and deposition were two to three times higher in downstream segments during the pre-stabilization period (table 3). However, during the post-stabilization period, there was an average decrease in both erosion and deposition of 4.3 and $7.9 \mathrm{~m}^{2} \mathrm{~m}^{-1}$ throughout all downstream segments (table 3 ). Some of this reduction is likely attributable to increased streambank strength and effective protection strategies, but there may be another causative factor, i.e., lateral migration and attendant changes prior to stabilization. The standard deviations of the erosion and deposition values for all but one of the downstream segments in the pre-stabilization period exceeded $13.2 \mathrm{~m}^{2} \mathrm{~m}^{-1}$ and ranged as high as $20.4 \mathrm{~m}^{2} \mathrm{~m}^{-1}$. Significant changes in river planform involving streambank erosion and meander cutoff probably occurred during this time in some stretches. In the upstream reaches, erosion increased by $0.53 \mathrm{~m}^{2} \mathrm{~m}^{-1}$ and deposition decreased by $1.7 \mathrm{~m}^{2} \mathrm{~m}^{-1}$.

Table 3. Statistics for each stream segment for all 24 sites were calculated for the periods before and after stabilization. Segments are listed from farthest upstream (US3) to farthest downstream (DS3).

\begin{tabular}{lccccc}
\hline Segment & $\begin{array}{c}\text { Min } \\
\left(\mathrm{m}^{2} \mathrm{~m}^{-1}\right)\end{array}$ & $\begin{array}{c}\text { Max } \\
\left(\mathrm{m}^{2} \mathrm{~m}^{-1}\right)\end{array}$ & $\begin{array}{c}\text { Median } \\
\left(\mathrm{m}^{2} \mathrm{~m}^{-1}\right)\end{array}$ & $\begin{array}{c}\text { Mean } \\
\left(\mathrm{m}^{2} \mathrm{~m}^{-1}\right)\end{array}$ & $\begin{array}{c}\mathrm{SD} \\
\left(\mathrm{m}^{2} \mathrm{~m}^{-1}\right)\end{array}$ \\
\hline Pre-stabilization (1993-2006) & & & & \\
US3 erosion & 0.0 & 30.7 & 1.9 & 3.3 & 4.8 \\
US3 deposition & 0.2 & 34.8 & 3.0 & 4.5 & 5.7 \\
\hline US2 erosion & 0.0 & 50.8 & 2.3 & 4.4 & 8.3 \\
US2 deposition & 0.1 & 37.7 & 3.4 & 5.1 & 6.5 \\
\hline US1 erosion & 0.0 & 22.5 & 1.9 & 3.0 & 4.6 \\
US1 deposition & 0.0 & 19.5 & 2.8 & 4.9 & 3.5 \\
\hline DS1 erosion & 0.0 & 23.0 & 1.4 & 4.2 & 14.7 \\
DS1 deposition & 0.0 & 124.5 & 4.0 & 9.7 & 6.1 \\
\hline DS2 erosion & 0.0 & 98.9 & 5.2 & 9.8 & 20.4 \\
DS2 deposition & 0.1 & 98.2 & 8.2 & 6.5 & 16.6 \\
\hline DS3 erosion & 0.0 & 93.0 & 6.3 & 9.1 & 13.2 \\
DS3 deposition & 0.0 & 81.0 & 5.4 & 5.5 & 16.6 \\
\hline Post-stabilization $(2006-2018)$ & & & & \\
US3 erosion & 0.2 & 14.3 & 3.2 & 3.8 & 2.9 \\
US3 deposition & 0.1 & 14.8 & 1.6 & 2.7 & 3.2 \\
\hline US2 erosion & 0.1 & 17.8 & 3.1 & 4.2 & 4.0 \\
US2 deposition & 0.0 & 16.9 & 1.4 & 2.6 & 3.0 \\
\hline US1 erosion & 0.0 & 27.5 & 2.6 & 4.3 & 5.1 \\
US1 deposition & 0.0 & 10.3 & 1.3 & 2.5 & 2.6 \\
\hline DS1 erosion & 0.0 & 22.3 & 2.0 & 3.9 & 4.7 \\
DS1 deposition & 0.0 & 27.2 & 0.7 & 2.9 & 5.1 \\
\hline DS2 erosion & 0.1 & 8.4 & 2.6 & 3.1 & 2.1 \\
DS2 deposition & 0.0 & 8.3 & 1.2 & 2.6 & 2.5 \\
\hline DS3 erosion & 0.0 & 8.4 & 2.6 & 3.1 & 2.1 \\
DS3 deposition & 0.1 & 9.3 & 0.8 & 1.8 & 2.2 \\
\hline
\end{tabular}


The increases in erosion in the other segments can be attributed to the 2010 flood and the present functionality of the streambank stabilization structures in each reach. Site 15 (fig. 4) is a case in point. The average annual erosion rate for the pre-stabilization period (1993-2006) at the stabilized bank was $0.43 \mathrm{~m}^{2} \mathrm{~m}^{-1}$, whereas the rate increased to $0.61 \mathrm{~m}^{2}$ $\mathrm{m}^{-1}$ during the post-stabilization period (2006-2010). The rate remained relatively high at $0.56 \mathrm{~m}^{2} \mathrm{~m}^{-1}$ during the postflood period (2010-2018). This reach exemplifies the nearly uniform trend of increased average bank erosion rates in segments with non-functional stabilization structures at the time of our visit (table 4).

Based on the ANOVA, the only significant differences in erosion during the pre- and post-stabilization periods occurred at segments DS2 and DS3 (table 4). The erosion at the two segments decreased from 9.8 and $9.1 \mathrm{~m}^{2} \mathrm{~m}^{-1}$ to $3.1 \mathrm{~m}^{2} \mathrm{~m}^{-1}$. To account for the influence of the structures that were no longer fully functional, we also conducted an ANOVA to evaluate the erosion between the two periods at only fully functional sites. A Fisher post-hoc test indicated that segments US1 and US2 (4.83 and $4.81 \mathrm{~m}^{2} \mathrm{~m}^{-1}$, respectively) during the post-stabilization period were significantly greater than segment US1 pre-stabilization $\left(2.2 \mathrm{~m}^{2} \mathrm{~m}^{-1}\right)$. Surprisingly, the average erosion for only the fully functional sites was greater than the average erosion for all 24 sites for four of the six segments.

Based on a Fisher post-hoc test, the mean deposition rate for segment DS1 during the pre-stabilization period $\left(9.93 \mathrm{~m}^{2}\right.$ $\mathrm{m}^{-1}$ ) was significantly greater than for the other segments. Segment DS3 during the post-stabilization period had the least amount of deposition $\left(1.8 \mathrm{~m}^{2} \mathrm{~m}^{-1}\right)$. When assessing only the
Table 4. ANOVA with Fisher post-hoc tests were conducted to evaluate significant differences in erosion and deposition between segments in the pre- and post-stabilization periods. Analysis was conducted for all 24 sites and for only the sites that were fully functional. Means followed by different letters are significantly different.

\begin{tabular}{|c|c|c|c|c|c|}
\hline \multicolumn{3}{|c|}{$\begin{array}{c}\text { Fully Functional Sites - } \\
\text { Deposition }\end{array}$} & \multicolumn{3}{|c|}{$\begin{array}{c}\text { Fully Functional Sites - } \\
\text { Erosion }\end{array}$} \\
\hline Segment & $N$ & Mean & Segment & $N$ & Mean \\
\hline DS2-Pre & 20 & $7.9 \mathrm{a}$ & US1-Pos & 22 & $4.8 \mathrm{a}$ \\
\hline US2-Pre & 24 & $5.9 \mathrm{ab}$ & US2-Pos & 22 & $4.8 \mathrm{a}$ \\
\hline DS3-Pre & 20 & $4.8 \mathrm{abc}$ & DS1-Pre & 22 & $4.1 \mathrm{ab}$ \\
\hline US1-Pre & 24 & $4.6 \mathrm{bc}$ & DS2-Pre & 20 & $3.9 \mathrm{ab}$ \\
\hline US3-Pre & 24 & $4.1 \mathrm{bc}$ & DS1-Pos & 22 & $3.9 \mathrm{ab}$ \\
\hline DS1-Post & 22 & $3.9 \mathrm{bc}$ & DS3-Pre & 18 & $3.7 \mathrm{ab}$ \\
\hline DS1-Pre & 22 & $3.7 \mathrm{bc}$ & DS2-Pos & 20 & $3.6 \mathrm{ab}$ \\
\hline US3-Pos & 24 & $2.7 \mathrm{c}$ & US2-Pre & 22 & $3.5 \mathrm{ab}$ \\
\hline US2-Pos & 24 & $2.7 \mathrm{c}$ & US3-Pos & 22 & $3.5 \mathrm{ab}$ \\
\hline US1-Pos & 24 & $2.3 \mathrm{c}$ & DS3-Pos & 18 & $3.4 \mathrm{ab}$ \\
\hline DS2-Pos & 20 & $2.2 \mathrm{c}$ & US3-Pre & 22 & $2.8 \mathrm{ab}$ \\
\hline DS3-Pos & 22 & $2.1 \mathrm{c}$ & US1-Pre & 22 & $2.2 \mathrm{~b}$ \\
\hline \multicolumn{3}{|c|}{ All Sites - Deposition } & \multicolumn{3}{|c|}{ All Sites - Erosion } \\
\hline Segment & $N$ & Mean & Segment & $N$ & Mean \\
\hline DS1-Pre & 44 & $9.7 \mathrm{a}$ & DS2-Pre & 42 & $9.8 \mathrm{a}$ \\
\hline DS2-Pre & 42 & $6.5 \mathrm{~b}$ & DS3-Pre & 40 & $9.1 \mathrm{a}$ \\
\hline DS3-Pre & 40 & $5.5 \mathrm{bc}$ & US2-Pre & 46 & $4.4 \mathrm{~b}$ \\
\hline US2-Pre & 46 & $5.1 \mathrm{bc}$ & US1-Pos & 46 & $4.3 \mathrm{~b}$ \\
\hline US1-Pre & 46 & $4.9 \mathrm{bcd}$ & DS1-Pre & 44 & $4.2 \mathrm{~b}$ \\
\hline US3-Pre & 46 & $4.5 \mathrm{bcd}$ & US2-Pos & 46 & $4.2 \mathrm{~b}$ \\
\hline DS1-Pos & 44 & $2.9 \mathrm{~cd}$ & DS1-Pos & 46 & $3.9 \mathrm{~b}$ \\
\hline US3-Pos & 46 & $2.7 \mathrm{~cd}$ & US3-Pos & 46 & $3.8 \mathrm{~b}$ \\
\hline US2-Pos & 46 & $2.6 \mathrm{~cd}$ & US3-Pre & 46 & $3.3 \mathrm{~b}$ \\
\hline DS2-Pos & 42 & $2.6 \mathrm{~cd}$ & DS2-Pos & 42 & $3.1 \mathrm{~b}$ \\
\hline US1-Pos & 46 & $2.5 \mathrm{~cd}$ & DS3-Pos & 40 & $3.1 \mathrm{~b}$ \\
\hline DS3-Pos & 40 & $1.8 \mathrm{~d}$ & US1-Pre & 46 & $3.0 \mathrm{~b}$ \\
\hline
\end{tabular}

functional reaches, segments DS2-Pre, US2-Pre, and DS3-Pre were significantly greater than most other segments (table 3).

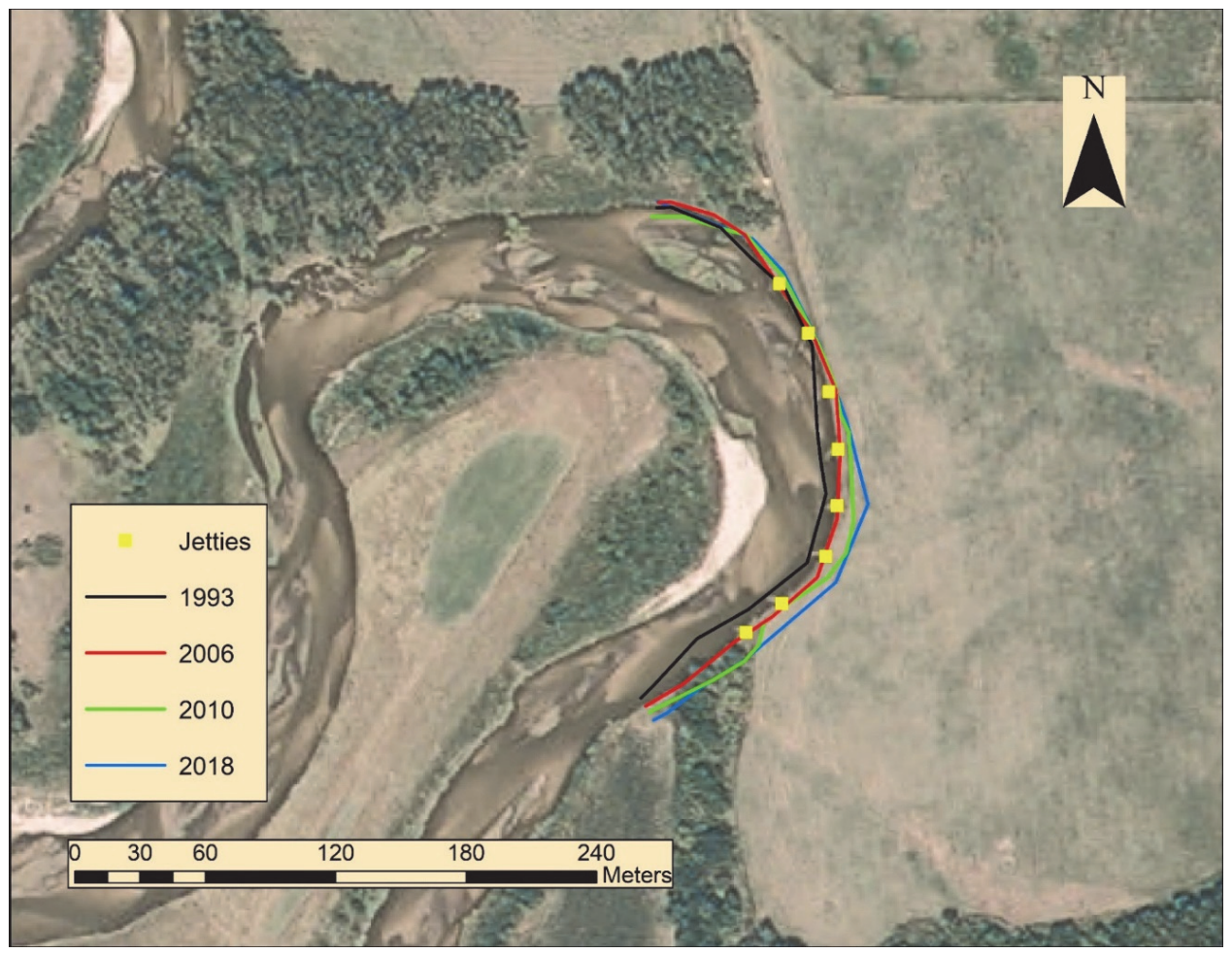

Figure 4. At site 15, the jetties installed prior to 2006 were no longer in place during our site visit in 2019, resulting in continued streambank retreat from 2006 to the present. 


\section{ERosion AND DEPOSITION Site ANALYSIS}

Tables 5 and 6 list the changes in erosion and deposition in each segment for both the right (R) and left (L) banks. The values are the post-stabilization erosion or deposition minus the pre-stabilization erosion or deposition. An example is shown in figure 5 , which compares the four sites that were stabilized with hardened structures, i.e., sloped gravel banks (sites 4, 5, and 10) and a reinforced concrete wall (site 7). We expected a reduction of erosion in the stabilized segments at all these sites. Furthermore, we did not expect any influence from the structures on upstream or downstream erosion nor on deposition. For sites 4 and 5, the sloped gravel bank was implemented in segment DS1R. This segment exhibited the largest reduction in erosion $\left(5.2 \mathrm{~m}^{2} \mathrm{~m}^{-1}\right.$ and
$7.2 \mathrm{~m}^{2} \mathrm{~m}^{-1}$ at sites 4 and 5, respectively). Site 7 did not experience any large changes in erosion or deposition, perhaps because of its proximity to Spalding Dam, where flows would have been more controlled than at any other sites. Site 10 had large reductions in erosion in both the US2R $\left(7.5 \mathrm{~m}^{2}\right.$ $\left.\mathrm{m}^{-1}\right)$ and DS2R $\left(6.1 \mathrm{~m}^{2} \mathrm{~m}^{-1}\right)$ segments. The sloped gravel bank at DS1L experienced a small increase in erosion $\left(0.17 \mathrm{~m}^{2} \mathrm{~m}^{-1}\right)$. The increase in erosion in segment US2R may have resulted from the jetties that were installed in segment US3R at site 11. The increased erosion at segment DS2L and the reduced deposition may be due to the proximity of site 10 to Ericson Dam (table 2 and fig. 1). Dave et al. (2020) found that the most erosion occurred within the first $10 \mathrm{~km}$ downstream of the dam.

Table 5. Changes in erosion from pre- to post-stabilization periods for hardened structures, fully functional structures, partially functional jetties, and non-functional jetties for each stream segment. Negative values indicate a reduction in erosion.

\begin{tabular}{|c|c|c|c|c|c|c|c|c|c|c|c|c|c|}
\hline & Site & US3R & US2R & US1R & DS1R & DS2R & DS3R & US3L & US2L & US1L & DS1L & DS2L & DS3L \\
\hline Hardened & 4 & 0.63 & 0.35 & -3.2 & -5.2 & -1.2 & 2.5 & 0.17 & -2.7 & 1.9 & 2.8 & 0.74 & 1.5 \\
\hline \multirow[t]{3}{*}{ structures } & 5 & 1.9 & -1.7 & 1.3 & -7.2 & -2.2 & -2.6 & 0.97 & 0.05 & -2.6 & 2.0 & 1.9 & 0.20 \\
\hline & 7 & N/A & -1.0 & 1.4 & -0.40 & -0.50 & -0.40 & N/A & -0.60 & -0.50 & 0.60 & 0.35 & -2.0 \\
\hline & 10 & -1.8 & 7.5 & 1.3 & 0.05 & -6.1 & 0.50 & -5.4 & 0.05 & -1.2 & 0.17 & 10.8 & 4.4 \\
\hline Fully & 2 & -0.13 & 0.17 & 2.0 & 3.2 & 1.0 & -8.2 & 0.82 & -7.3 & -1.5 & 4.1 & -6.5 & 1.9 \\
\hline \multirow{7}{*}{$\begin{array}{c}\text { functional } \\
\text { jetties }\end{array}$} & 11 & 2.1 & -1.1 & -3.2 & -10.4 & -0.56 & -4.2 & -1.4 & 14.4 & 1.2 & 6.2 & -1.1 & -0.24 \\
\hline & 12 & -1.0 & -0.20 & 1.7 & -2.8 & 0.30 & -0.80 & 1.2 & -1.1 & 0.84 & 0 & 3.2 & -2.8 \\
\hline & 13 & 1.5 & 1.4 & 3.2 & N/A & N/A & N/A & 2.6 & 9.0 & 0.64 & N/A & N/A & -2.8 \\
\hline & 14 & 1.3 & 1.3 & 2.0 & 0.5 & N/A & N/A & -4.5 & -2.8 & -7.0 & 9.9 & N/A & N/A \\
\hline & 19 & 6.8 & 0.56 & -2.6 & -3.6 & 1.7 & -1.1 & -0.05 & 2.1 & 1.7 & -11.1 & -1.4 & -18.3 \\
\hline & 22 & 5.1 & 0.63 & -2.2 & 11.3 & 0.44 & -0.11 & 0.95 & 3.0 & 1.1 & -0.46 & 2.5 & -1.4 \\
\hline & 23 & 5.1 & 0.63 & -2.2 & 11.3 & 0.44 & -0.10 & 0.95 & 3.0 & 1.1 & -0.50 & 2.5 & -1.4 \\
\hline \multirow{6}{*}{$\begin{array}{c}\text { Partially } \\
\text { functional } \\
\text { jetties }\end{array}$} & 1 & -1.2 & 1.0 & 0.66 & 0.36 & -0.76 & 0.51 & 1.3 & 0.16 & -2.2 & -1.1 & 0.80 & -1.2 \\
\hline & 3 & -1.1 & 0.65 & -3.1 & -0.60 & -1.1 & 1.7 & -0.80 & -1.7 & 1.7 & 2.8 & 0.20 & -0.50 \\
\hline & 6 & 4.9 & -4.1 & 1.7 & -5.8 & -1.5 & 2.9 & 2.3 & -0.30 & -1.8 & 0.96 & -1.0 & 0.40 \\
\hline & 8 & 0.92 & -2.5 & -6.8 & -0.60 & 13.9 & 0.18 & -0.10 & -2.5 & 0.92 & 0.0 & -16.4 & 2.6 \\
\hline & 9 & 0.82 & -0.60 & 0.79 & -9.4 & 0.70 & -2.1 & 0.80 & 2.4 & 4.5 & 2.3 & 8.1 & 2.0 \\
\hline & 21 & 2.6 & 2.3 & 7.2 & 0.33 & -7.1 & -0.12 & 6.7 & 15.4 & 22.0 & 4.3 & 5.0 & 5.0 \\
\hline \multirow{6}{*}{$\begin{array}{c}\text { Non- } \\
\text { functional } \\
\text { jetties }\end{array}$} & 15 & 0.39 & -6.1 & 0.34 & -1.1 & 2.2 & N/A & -0.04 & -3.3 & 1.6 & 2.7 & -17.0 & N/A \\
\hline & 16 & 1.4 & -4.6 & -4.5 & -5.3 & -0.73 & 0.07 & -2.7 & -2.6 & -2.7 & 0.30 & 3.3 & -1.1 \\
\hline & 17 & -4.4 & -1.7 & 0.36 & -0.50 & -0.80 & -1.1 & -3.5 & 0.26 & 18.4 & 7.0 & -1.0 & 2.4 \\
\hline & 18 & -0.70 & -3.2 & 7.5 & 0.0 & -4.8 & -3.0 & 1.1 & 1.1 & 8.8 & 0.70 & 2.7 & 3.5 \\
\hline & 20 & -0.14 & 3.0 & 1.8 & 1.6 & 3.8 & -8.1 & 3.8 & 7.8 & 3.0 & -1.2 & 3.1 & -5.6 \\
\hline & 24 & 5.4 & 6.9 & -7.2 & 13.2 & -3.6 & 1.5 & -0.47 & 2.8 & 11.2 & -1.6 & -4.5 & -2.6 \\
\hline
\end{tabular}

Table 6. Changes in deposition from pre- to post-stabilization periods for hardened structures, fully functional structures, partially functional jetties, and non-functional jetties for each stream segment. Negative values indicate a reduction in erosion.

\begin{tabular}{|c|c|c|c|c|c|c|c|c|c|c|c|c|c|}
\hline & Site & US3R & US2R & US1R & DS1R & DS2R & DS3R & US3L & US2L & US1L & DS1L & DS2L & DS3L \\
\hline Hardened & 4 & -2.4 & -13.3 & 1.7 & 4.2 & -2.9 & -1.7 & -13.7 & 2.4 & -4.7 & -10.3 & -5.4 & -8.7 \\
\hline \multirow[t]{3}{*}{ structures } & 5 & -4.1 & -1.6 & -5.8 & 0.70 & 0.0 & -1.9 & 9.3 & -5.0 & 2.0 & -6.0 & -3.8 & -12 \\
\hline & 7 & N/A & -0.45 & -0.40 & 0.36 & -0.20 & -0.40 & N/A & -1.8 & 0.40 & 0.40 & -2.6 & -0.13 \\
\hline & 10 & -5.4 & -2.5 & -4.0 & -9.2 & 0.70 & -3.6 & -4.3 & -17 & -5.9 & -12.6 & -22.2 & -2.9 \\
\hline Fully & 2 & -0.80 & 1.5 & -5.5 & -1.1 & -6.0 & 0.40 & -2.2 & 1.9 & -7.2 & -1.1 & 0.26 & -14.8 \\
\hline functional & 11 & 0.42 & -2.0 & -2.6 & -4.2 & 0.04 & 0.04 & -0.91 & -10.1 & -6.5 & -27.7 & -10.2 & -4.6 \\
\hline \multirow[t]{6}{*}{ structures } & 12 & 0.75 & 10 & -4.0 & 0.50 & -4.4 & -4.4 & -1.0 & -1.8 & 3.1 & 4.1 & -6.1 & -0.40 \\
\hline & 13 & 3.5 & 0.20 & 1.8 & N/A & N/A & N/A & -0.02 & -29.9 & -1.1 & N/A & N/A & $\mathrm{N} / \mathrm{A}$ \\
\hline & 14 & -0.2 & -0.40 & -20 & -120 & N/A & N/A & 0.42 & 4.5 & -0.60 & -60 & N/A & N/A \\
\hline & 19 & -4.2 & 3.4 & -0.20 & -18.6 & -0.71 & 0.02 & 1.9 & 0.15 & 1.1 & -0.40 & 3.0 & 0.02 \\
\hline & 22 & -6.8 & -1.8 & -1.1 & -7.3 & -0.80 & -1.3 & -2.2 & -4.8 & -3.2 & -0.30 & -1.1 & -1.3 \\
\hline & 23 & -6.8 & -1.8 & -1.1 & -7.3 & -0.80 & -1.3 & -2.2 & -4.8 & -3.3 & -0.30 & -1.1 & -1.3 \\
\hline \multirow{6}{*}{$\begin{array}{c}\text { Partially } \\
\text { functional } \\
\text { jetties }\end{array}$} & 1 & -1.1 & 2.6 & -1.6 & -3.8 & 0.50 & -4.0 & -0.90 & -1.4 & 2.3 & -0.80 & -1.9 & 2.5 \\
\hline & 3 & -4.9 & -3.0 & -0.50 & -4.7 & -1.9 & -18.6 & -5.1 & -0.12 & -8.6 & -2.2 & -17 & 0.45 \\
\hline & 6 & -14.4 & -0.40 & 6.2 & 0.90 & 0.50 & -12.1 & -4.5 & -9.2 & -3.3 & -1.3 & 1.5 & 0.07 \\
\hline & 8 & -0.66 & -0.02 & 0.0 & -0.47 & -24.5 & -4.4 & -3.2 & 0.0 & -1.5 & 0.95 & 6.5 & -6.7 \\
\hline & 9 & 0.2 & -1.4 & -7.8 & 1.1 & -1.5 & 0.0 & 12.3 & -3.5 & -3.0 & -10.7 & -6.5 & -5.1 \\
\hline & 21 & -4.0 & -0.10 & -0.2 & -4.5 & -2.8 & -2.0 & -7.1 & -1.2 & -2.2 & -7.1 & -8.8 & -15 \\
\hline \multirow{6}{*}{$\begin{array}{l}\text { Non- } \\
\text { functional } \\
\text { jetties }\end{array}$} & 15 & 2.6 & 0.65 & -1.1 & 0.28 & -28.9 & N/A & 0.73 & 0.41 & 2.0 & -5.8 & -1.0 & $\mathrm{~N} / \mathrm{A}$ \\
\hline & 16 & -2.3 & 4.6 & 0.7 & 0.10 & -2.0 & -1.1 & -3.4 & -0.90 & -2.4 & -2.0 & -2.0 & 1.4 \\
\hline & 17 & 4.0 & -0.70 & -6.3 & -0.50 & -1.4 & 0.80 & -0.60 & -1.0 & -10.1 & -0.10 & 0.0 & -0.45 \\
\hline & 18 & -1.9 & -1.4 & -12.3 & -12.9 & 4.3 & 1.8 & -5.7 & -12.6 & -9.3 & -1.2 & -9.2 & -4.2 \\
\hline & 20 & -1.6 & -4.1 & -1.9 & 0.0 & -2.1 & -1.8 & -9.4 & -5.6 & 2.3 & -6.0 & -3.2 & -7.4 \\
\hline & 24 & -4.7 & -5.1 & 8.5 & -3.8 & 1.4 & -0.81 & 6.2 & -3.6 & 1.3 & 1.5 & -7.4 & 4.8 \\
\hline
\end{tabular}



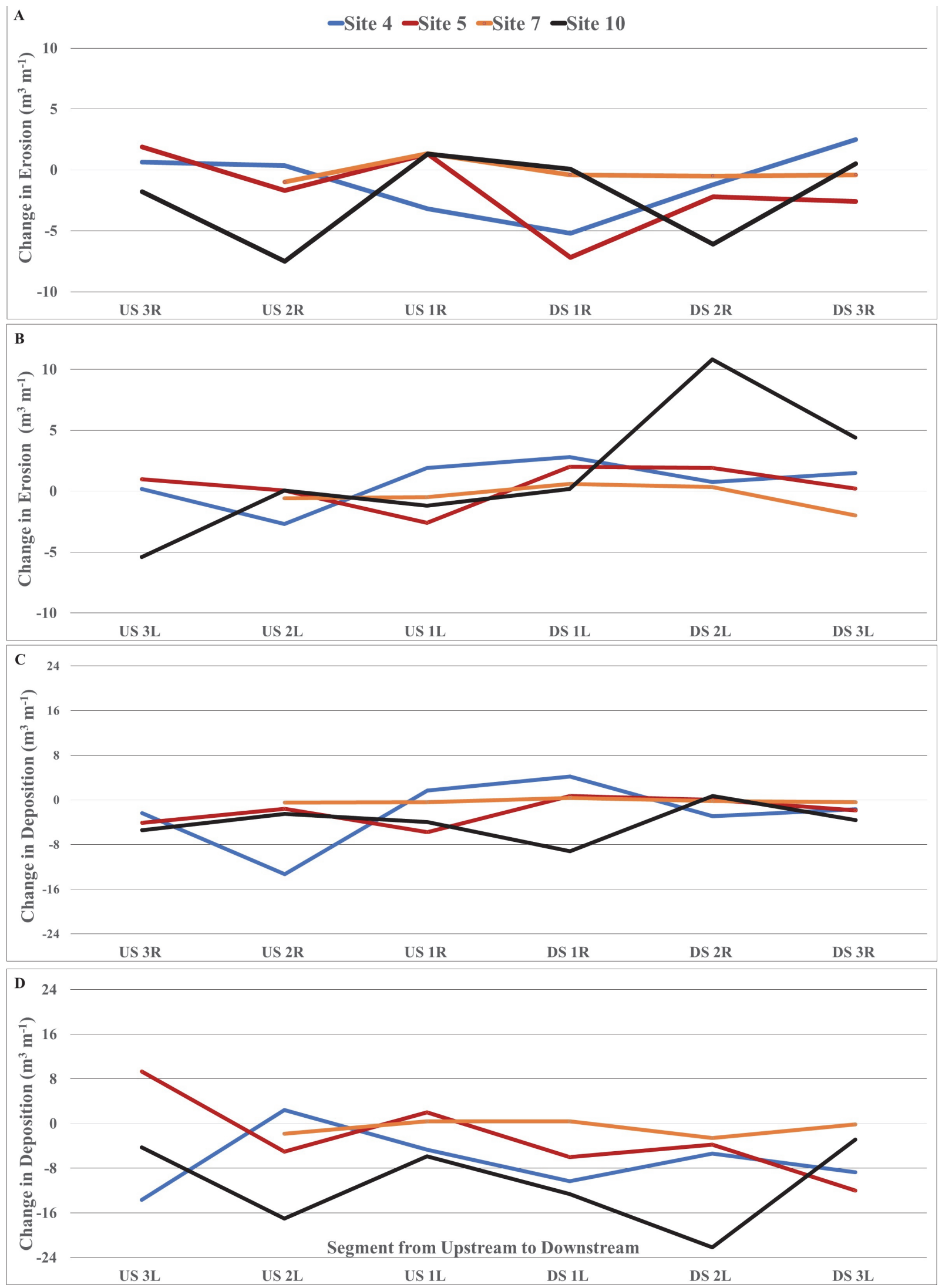

Figure 5. Changes in erosion and deposition at sites 4, 5, 7, and 10 (hardened structures) from the post- and pre-stabilization periods for the right and left banks for the six segments. 
Tables 5 and 6 list the erosion and deposition for the fully functional sites (sites 2, 11, 12, 13, 14, 19, 22, and 23 ). Sites 2 and 13 were stabilized with rock vanes, site 12 with root wads, sites 11 and 14 with wooden jetties, and sites 19, 22, and 23 with tree jetties. Sites 2, 11, and 19 had the largest reductions in erosion. Rock vanes were installed in segment DS1R at site 2, where the erosion actually increased from 0.1 to $3.3 \mathrm{~m}^{2} \mathrm{~m}^{-1}$ from the pre- to post-stabilization periods. However, the rock vanes only protected $13 \%$ of the segment. Segments DS3R, US2L, and DS2L at site 2 had large reductions in erosion that were probably unrelated to the rock vanes. At site 11, wooden jetties were installed in segments DS1R and US1R, where the erosion decreased from 16.3 to $5.9 \mathrm{~m}^{2} \mathrm{~m}^{-1}$ and from 4.4 to $1.2 \mathrm{~m}^{2}$ $\mathrm{m}^{-1}$, respectively. Site 19 overlapped with site 15 , where wooden jetties were installed in segments US1R and DS1L, which would explain the reductions in erosion from 6.1 to $3.5 \mathrm{~m}^{2} \mathrm{~m}^{-1}$ in segment US1R and from 21.5 to $10.4 \mathrm{~m}^{2} \mathrm{~m}^{-1}$ in segment DS1L. We are not sure why there was a large reduction at site 19 in segment DS3L. At site 12, the root wads helped reduce the erosion from 6.1 to $3.3 \mathrm{~m}^{2} \mathrm{~m}^{-1}$. Erosion at site 13 in segment US1R, where the rock vane was installed, increased from 0.9 to $2.7 \mathrm{~m}^{2} \mathrm{~m}^{-1}$. This is likely because only $20 \%$ of the segment was stabilized (table 1 ). The reduction in erosion in each of the upstream segments at site 14 is attributed to the jetties that protected $45 \%$ of the reach in segment US1L.

Site 22 did not have any large reductions in erosion, but the wooden jetties only stabilized $8.9 \%$ of segment US1R. The largest increases in erosion were at sites 11 (US2L), 13 (US2L), 14 (DS1L), and 22 (DS1R). We anticipated that the sites stabilized with wooden jetties (sites 11 and 14) would have experienced the most deposition, but some of our results do not support this a priori hypothesis. The increase in erosion, rather than deposition, at site 11 may have resulted from its comparative proximity to Ericson Dam $(8 \mathrm{~km})$ and the potential that the 2010 dam-breach flood may have removed any deposition that had accumulated there prior to the flood sediment. The deposition in segment US2L at site 14 probably resulted from the effects of the wooden jetties in segment US1L. Sites 13 and 14 were not fully evaluated because an oxbow formed there during the study period. Furthermore, in the upstream segments of site 13, deposition and erosion varied from pre- to post-stabilization due in large part to the creation of a midchannel bar in segment US2. Flow diverged around the newly created midchannel bar, and the divergent flow promoted deposition immediately upstream of the bar. The change in direction created a considerable difference in the amount of erosion and deposition in US2. Similarly, we observed a considerable decrease in deposition at site 14 . This was again due to a large shift in the river's direction, which was briefly caught and described by the differences in deposition and erosion found in segments DS1L and DS1R.

There were six sites (sites 1, 3, 6, 8, 9, and 21) where some of the jetties were damaged or missing. Sites 6,9 , and 21 had large reductions in erosion in downstream segments after they were stabilized (table 5). At site 6, erosion decreased from 6.2 to $0.45 \mathrm{~m}^{2} \mathrm{~m}^{-1}$ in segment DS1R, where $38 \%$ of the segment was stabilized with wooden jetties. At site 9 , the erosion was reduced from 10.3 to $0.9 \mathrm{~m}^{2} \mathrm{~m}^{-1}$, also in segment DS1R; $29.4 \%$ of this segment was stabilized with wooden jetties.

The reduction in erosion at site 21 in segment DS2 may be due to the jetties installed in segment DS1R at site 9, which overlaps with site 21. Although segment US1L was stabilized with jetties at site 21 , there was a large increase in erosion. This is attributed to the jetties failing, most likely from the 2010 flood. At site 6, there was increased deposition in segments US1R and DS1R (table 6), most likely from the jetties installed in segment DS1R. There was also a slight increase in erosion in segment DS1R at site 9, the same segment where the jetties were located. Site 21 did not have any segments with increased deposition, likely due to jetty failure.

Five sites classified as non-functional in terms of stabilization (sites 16, 17, 18, 20, and 24) exhibited both variable erosion and deposition (tables 5 and 6.). More than $50 \%$ of segment DS1R was stabilized at site 16. Although the jetties were either buried or washed away, the erosion decreased from 12.7 to $7.4 \mathrm{~m}^{2} \mathrm{~m}^{-1}$ at segment DS1R. At sites 17 and 24 , the erosion increased from 0 to $18.4 \mathrm{~m}^{2} \mathrm{~m}^{-1}$ and from 1.3 to $14.5 \mathrm{~m}^{2} \mathrm{~m}^{-1}$, respectively, at the stabilized segment. There was also increased erosion at the stabilized segment at sites 18 and 21. Overall, there was decreased deposition at the five sites where the jetties were no longer functional. The only exception was site 24, where there were large quantities of deposition in segments DS3L, US1R, and US3L. Other than the deposition in US1R, the increase is probably not related to the jetties that were installed in segment DS1R.

With the complexity of the system and all of the variables, it is challenging to draw any definitive conclusions concerning the influence of the stabilization structures on adjacent stream segments. While the erosion in segments DS2 and DS3 was significantly greater during the pre-stabilization period, we cannot fully attribute this reduction to the stabilization structures. The large reduction in erosion in segment DS2 was mostly due to the reduction in segment DS2L from 17 to $0.85 \mathrm{~m}^{2} \mathrm{~m}^{-1}$. Jetties were installed in segment US1R, which probably had no impact on segment DS2L. In segment DS3, most of the reduction in erosion was from DS3R (20 to $1.3 \mathrm{~m}^{2} \mathrm{~m}^{-1}$ ). Jetties were installed in segment US1L, which surely had no impact on segment DS3R.

Figure 6 shows the average erosion and deposition for the pre- and post-stabilization periods in the stabilized segment for the hardened structures, fully functional jetties, partially functional jetties, and non-functional jetties. There are clear reductions in erosion for the sites stabilized with hardened structures, fully functional jetties, and partially functional jetties. For the segment immediately upstream, the sites stabilized with hardened structures and non-functional jetties had less erosion during the post-stabilization period $\left(2.9\right.$ to $1.1 \mathrm{~m}^{2}$ $\mathrm{m}^{-1}$ and 4.9 to 3.0 , respectively), but erosion increased for the fully functional and partially functional jetties. For the segment immediately downstream, erosion increased for the sites stabilized with hardened structures and partially functional jetties but decreased for the sites with fully functional jetties. Based on the Fisher post-hoc test, non-functional jetties in the segment with the stabilization structure $\left(13.4 \mathrm{~m}^{2} \mathrm{~m}^{-1}\right)$ were significantly greater than in the segment with hardened 

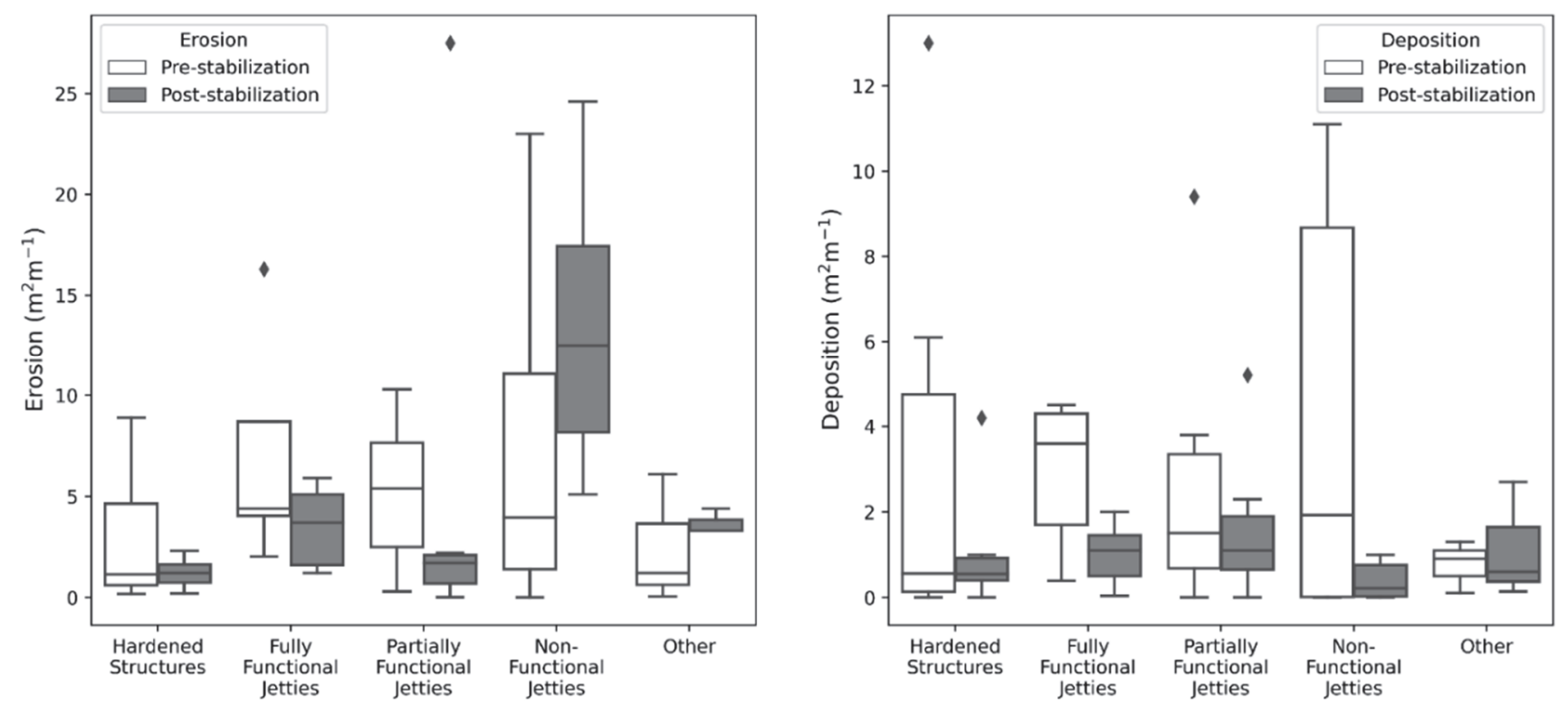

Figure 6. Erosion and deposition for the pre- and post-stabilization periods for hardened structures, fully functional jetties, partially functional jetties, non-functional jetties, and other (root wad and rock vanes).

structures post-stabilization $\left(1.2 \mathrm{~m}^{2} \mathrm{~m}^{-1}\right)$, the hardened structures post-stabilization in the segment upstream of the stabilization structure $\left(1.1 \mathrm{~m}^{2} \mathrm{~m}^{-1}\right)$, and the partially functional jetties for the pre-stabilization period in the segment upstream where the jetties were installed $\left(2.0 \mathrm{~m}^{2} \mathrm{~m}^{-1}\right)$.

Dave and Mittelstet (2017) concluded that stabilization structures on the Cedar River reduced erosion locally by decreasing the stream power acting on the newly stabilized area. The amount of stream power reduction, and the method in which it was reduced, largely depended on the type of structure installed and the location of the segment where it was installed. Our results verify their conclusion. The stabilized section at reach 11 (fig. 7) nearly matches the 2006 and 2018 bank lines. This close correspondence of bank position over time indicates that bank stabilization has succeeded. Conversely, nearly every other segment of the reach saw considerable bank migration both before and after jetties were installed. Based on our findings, stabilization structures have little impact on upstream and downstream stream segments.

\section{CONCLUSIONS}

The local effectiveness of streambank stabilization structures in reducing, and in some cases eliminating, streambank erosion is well documented. However, the complexities of constantly changing stream planforms, varying erosion and deposition processes, and whole-watershed dynamics complicate determining the success or failure of bank stabilization. We measured streambank erosion and deposition in 24 stretches of the Cedar River, 1.5 wavelengths upstream and downstream from 24 stabilization structures. While jetties and hardened structures reduced erosion in the stabilized segment, rock vanes were less successful. Analysis of these
24 segments ultimately led us to reject an initial hypothesis that erosion would decrease in local and adjacent segments after stabilization. Instead, the differences in erosion from pre- to post-stabilization showed little or no statistical significance, and deposition was actually greater during the prestabilization period.

We conclude that streambank stabilization on the Cedar River is effective only at the location of installation. Other than an increase in deposition due to jetties, we found no measurable effect of such stabilization on any adjacent unstabilized reaches. These results reveal an acute need for additional critical research regarding streambank stabilization. The following goals should be addressed by such research:

- Improved methods and increased frequency of postinstallation streambank monitoring.

- Additional research on the systemic (whole-watershed) impacts of streambank stabilization.

- Improved designs and installation protocol for streambank stabilization structures.

- Evaluation of the relationships between woody vegetation and the success or failure of streambank stabilization structures.

Any of these advances has potential to enhance stream restoration and effective river management efforts.

\section{ACKNOWLEDGEMENTS}

This project was funded by the Nebraska Environmental Trust (Award No. 110671). The authors would like to thank Janet Sanders of the Loup Basin RC\&D Council and Ed Hovet. 


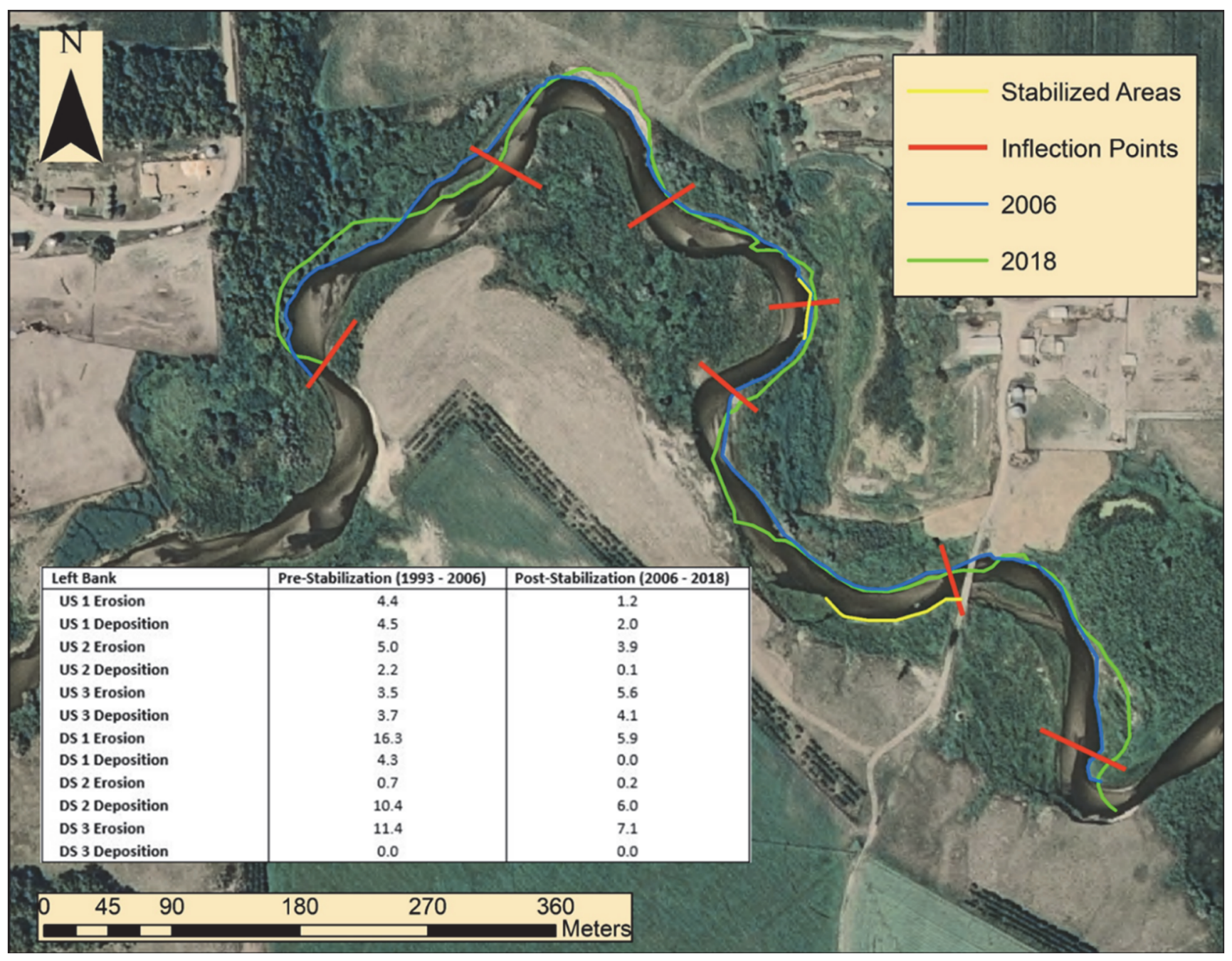

Figure 7. At site 11, erosion and deposition occurred in all segments prior to stabilization. After installation, erosion ceased in the stabilized area. Only the right bank lines and stabilized areas are shown.

\section{REFERENCES}

Anstead, L., Boar, R. R., \& Tovey, N. K. (2012). The effectiveness of a soil bioengineering solution for river bank stabilisation during flood and drought conditions: Two case studies from East Anglia. Area, 44(4), 479-488. https://doi.org/10.1111/j.14754762.2012.01132.x

Bhuiyan, F., Hey, R. D., \& Wormleaton, P. R. (2009). Effects of vanes and $\mathrm{W}$-weir on sediment transport in meandering channels. J. Hydraul. Eng., 135(5), 339-349. https://doi.org/10.1061/(ASCE)0733-9429(2009)135:5(339)

Bigham, K. A. (2020). Streambank stabilization design, research, and monitoring: The current state and future needs. Trans. ASABE, 63(2), 351-387. https://doi.org/10.13031/trans.13647

Buchanan, B. P., Nagle, G. N., \& Walter, M. T. (2014). Long-term monitoring and assessment of a stream restoration project in central New York. River Res. Appl., 30(2), 245-258. https://doi.org/10.1002/rra.2639

Castro-Bolinaga, C. F., \& Fox, G. A. (2018). Streambank erosion: Advances in monitoring, modeling, and management. Water, 10(10), 1346. https://doi.org/0.3390/w10101346

Cooperman, M. S., Hinch, S. G., Bennett, S., Branton, M. A., Galbraith, R. V., Quigley, J. T., \& Heise, B. A. (2007). Streambank restoration effectiveness: Lessons learned from a comparative study. Fisheries, 32(6), 278-291. https://doi.org/10.1577/1548

8446(2007)32[278:SRELFA]2.0.CO;2

Couper, P. R. (2004). Space and time in river bank erosion research: A review. Area, 36(4), 387-403. https://doi.org/10.1111/j.00040894.2004.00239.x

Dave, N., \& Mittelstet, A. R. (2017). Quantifying effectiveness of streambank stabilization practices on Cedar River, Nebraska. Water, 9(12), article 930. https://doi.org/10.3390/w9120930

Dave, N., Mittelstet, A., Korus, J., \& Waszgis, M. (2020). Impact of an extreme flood event on streambank retreat: Cedar River, Nebraska. JAWRA, 56(3), 528-541. https://doi.org/10.1111/1752-1688.12828

Enlow, H. K., Fox, G. A., Boyer, T. A., Stoecker, A., Storm, D. E., Starks, P., \& Guertault, L. (2018). A modeling framework for evaluating streambank stabilization practices for reach-scale sediment reduction. Environ. Model. Software, 100, 201-212. https://doi.org/10.1016/j.envsoft.2017.11.010

Florsheim, J. L., Mount, J. F., \& Chin, A. (2008). Bank erosion as a desirable attribute of rivers. BioScience, 58(6), 519-529.

Fox, G. A., Purvis, R. A., \& Penn, C. J. (2016). Streambanks: A net source of sediment and phosphorus to streams and rivers. $J$. Environ. Mgmt., 181, 602-614.

https://doi.org/10.1016/j.jenvman.2016.06.071 
Heeren, D. M., Mittelstet, A. R., Fox, G. A., Storm, D. E., AlMadhhachi, A. T., Midgley, T. L., ... Tejral, R. D. (2012). Using rapid geomorphic assessments to assess streambank stability in Oklahoma Ozark streams. Trans. ASABE, 55(3), 957-968. https://doi.org/10.13031/2013.41527

Khosronejad, A., Kozarek, J. L., Diplas, P., Hill, C., Jha, R., Chatanantavet, P., ... Sotiropoulos, F. (2018). Simulation-based optimization of in-stream structures design: Rock vanes. Environ. Fluid Mech., 18(3), 695-738. https://doi.org/10.1007/s10652-018-9579-7

Leopold, L. B., \& Wolman, M. G. (1957). River channel patterns: Braided, meandering, and straight. USGS Professional Paper 282B. Reston, VA: U.S. Geological Survey. https://doi.org/10.3133/pp282B

Loup Basin RC\&D. (2021). Cedar River Stabilization Project. Burwell, NE: Loup Basin RC\&D Council. Retrieved from http://loupbasinrcd.org/projects/ cedar-river-stabilizaton-project/

Pizzuto, J. E. (2008). Chapter 7: Streambank erosion and river width adjustment. In Sedimentation engineering: Processing, measurements, modeling, and practice (pp. 387-438). Reston, VA: ASCE. https://doi.org/10.1061/9780784408148.ch07
Reid, D., \& Church, M. (2015). Geomorphic and ecological consequences of riprap placement in river systems. JAWRA, 51(4), 1043-1059. https://doi.org/10.1111/jawr.12279

NEDNR. (2021). Nebraska interactive streamgage map. Omaha, NE: Nebraska Department of Natural Resources. Retrieved from https://nednr.nebraska.gov/RealTime/

Rosgen, D. L. (1996). Applied river morphology (2nd Ed.). Pagosa Springs, CO: Wildland Hydrology.

Russell, M., Mittelstet, A. R., Messer, T. L., \& Korus, J. (2021). Quantification of erosional and depositional processes near implemented streambank stabilization practices. Ecol. Eng., in review.

Simon, A., Curini, A., Darby, S. E., \& Langendoen, E. J. (2000). Bank and near-bank processes in an incised channel. Geomorphology, 35(3), 193-217. https://doi.org/10.1016/S0169555X(00)00036-2

Wohl, E., Lane, S. N., \& Wilcox, A. C. (2015). The science and practice of river restoration. Water Resour. Res., 51(8), 59745997. https://doi.org/10.1002/2014WR016874 